\title{
Cinema, poesia e história: uma leitura do filme El espíritu de la colmena de Victor Erice
}

\author{
Maria Ignês Carlos Magno \\ Doutora em Ciências da Comunicação pela Escola de Comunicações e Artes da Universidade \\ de São Paulo (ECA-USP) e professora do Programa de Pós-graduação em Comunicação da \\ Universidade Anhembi Morumbi \\ E-mail: unsigster@gmail.com
}

Resumo: O filme El espíritu de la colmena (1973) de Victor Erice é considerado um dos mais belos do cinema espanhol dos anos 1970. O filme, além de articular internamente a complexa rede de significados que a Guerra Civil e o franquismo desempenharam na história e na cultura espanhola, permite que nosso olhar perceba outras sutilezas e estratégias utilizadas pelo diretor para construir sua narrativa. Uma delas é a poesia. E como muitas das imagens do filme nos reportam para alguns dos poemas de Antonio Machado, proponho para esta resenha o exercício de ver como Victor Erice entrelaçou imagens e poesias para falar de um dos períodos mais trágicos da história espanhola.

Palavras-chave: cinema espanhol; Guerra Civil Espanhola; poesia; Antonio Machado; Miguel de Unamuno.
Abstract: Victor Erice's El espíritu de la colmena (1973) is considered one of the most beautiful Spanish films from the 1970s. The film, in addition to internally articulating the complex network of meanings that the Civil War and Francoism played in Spanish history and culture, shows other subtleties and strategies used by the director to construct his narrative. One of them is poetry itself. And since many of the images in the film tell us about some of Antonio Machado's poems read from Miguel de Unamuno's perspective, I propose for this review the exercise of seeing how Victor Erice intertwined images and poetry to speak of one of the most tragic periods in Spanish history.

Keywords: Spanish cinema; Civil War Spanish; poetry; Antonio Machado; Miguel de Unamuno. 
comunicação \& educação • Ano XXV • número 1 • jan/jun 2020

No hay más diálogo verdadero que el diálogo que entablas
contigo mismo, y este diálogo sólo puedes entablarlo
estando a solas. Em la soledad, y sólo em la soledad

(Miguel de Unamuno. Soledad, 1905) ${ }^{1}$

\section{INTRODUÇÃO}

Adentrar um campo e um universo de leitura para o qual os olhos não foram educados é sempre uma dificuldade. Compreender metáforas, metonímias e condensações em textos fílmicos é um desafio tanto quanto transitar entre o desejo de entender o específico fílmico e a poética existente na construção de alguns filmes que assistimos e não conseguimos deixar de pensar, passe o tempo que passar. Filmes que voltam à tona quando menos esperamos, ou quando vivemos momentos históricos que nos perturbam e nos colocam frente a uma história que parecia fazer parte de um passado distante. Um desses filmes que sempre me acompanhou é El espíritu de la colmena ${ }^{2}$ ( $O$ espírito da colmeia, 1973) de Victor Erice. O impacto textual, histórico e visual causado à época em que o assisti me desafiou e me levou ao exercício, mais propriamente, a um dos muitos exercícios possíveis: perceber como alguns cineastas espanhóis dos anos 1960 e 1970 organizaram e articularam, no interior de seus filmes, a complexa rede de significados que a Guerra Civil e o franquismo representaram na cultura espanhola daqueles anos.

Naquele momento, considerar que muitos dos filmes espanhóis que comSoledad. In: Obras completas. Madrid: A. Aguado, 1958. t. 3, p. 881-901. p. 883. "Não existe diálogo mais verdadeiro do que você tem consigo mesmo, e esse diálogo só pode ser iniciado por você mesmo. Na solidão, e somente na solidão" (tradução nossa). Para não perder o sentido e nem a sonoridade das poesias, as citações serão mantidas em espanhol. As devidas traduções e referências serão colocadas em nota de rodapé.

2.EL ESPÍRITU de la Colmena. Direção de Victor Erice. Roteiro de Victor Erice e Angel Fernandez Santos. Produção de Elias Querejeta. Música de Luis de Pablo. Fotografia de Luis Cuadrado. Montagem de Pablo G. Del Amo. [S. I.]: Elías Querejeta Producciones Cinematográficas S.L., 1973. punham a produção dos anos 1960 e 1970 faziam parte de uma vertente que cultivava a parábola política, ou ainda, que todos, direta ou indiretamente, aludiam e estavam impregnados da guerra e da interferência franquista nos parecia óbvio. Atentando para o fato de que o óbvio não é necessariamente o que está dado, mas, às vezes, é o ocultado, interessava investir e tentar desvendar aspectos escondidos por detrás da aparente obviedade. Aspectos que residiam nas sutilezas das metáforas construídas por aquela geração de cineastas, que queriam falar de uma história que, nas palavras de Albert Camus, ainda "é como uma ferida que não fecha" ${ }^{3}$ na memória daqueles que lutaram pela liberdade. Uma ferida sangrenta para aqueles que, a despeito do tempo e da ditadura continuaram lutando e produzindo. Embora Erice diga que o mito de Frankenstein e a contemplação de uma sociedade instintiva, porém, perfeitamente organizada como a das abelhas, tenham sido a inspiração do filme, é possível ver como a Guerra Civil Espanhola está presente em todo a obra.

Se no ano de 1995 o que mais chamava a atenção era a forma como Victor Erice havia construído visualmente seu diálogo com a história espanhola, o reencontro com o filme, além de reafirmar o quanto a impactante beleza visual e textual permanecem no interior de nós mesmos, permite que nosso olhar perceba outras sutilezas e estratégias utilizadas pelo diretor para construir poeticamente sua narrativa. Uma dessas estratégias é a própria poesia. 
E como muitas das imagens de El espiritu de la colmena parecem ter suas matrizes em alguns dos poemas de Antonio Machado, proponho para esta resenha um outro exercício: tentar mostrar como Victor Erice entrelaçou imagens e poesias para falar de um dos períodos mais trágicos da história espanhola.

\section{O FILME, A HISTÓRIA E A POESIA}

O filme El espiritu de la colmena de Victor Erice narra uma história aparentemente simples: em um pequeno povoado espanhol, em 1940, duas crianças assistem ao filme Frankenstein (1933) de James Whale e ficam obcecadas com a personagem do filme. Uma delas desaparece por um breve período, o que agrava ainda mais a obsessão da outra menina pelo monstro. E a simplicidade termina aqui.

Começando pelo título, que foi extraído do livro do poeta e dramaturgo Maurice Maeterlinck, que Erice diz utilizar a expressão "El espíritu de la colmena" para descrever o espírito todo poderoso, enigmático e paródico que as abelhas parecem obedecer e que os homens jamais conseguiram compreender. É importante destacar, como fatos históricos que influenciam na construção da narrativa, que em $1^{\circ}$ de abril de 1939 Francisco Franco declarava o fim da Guerra Civil na Espanha (1936-1939), assim como interessa saber que o bombardeio da cidade de Guernica (1936) e o início da Segunda Guerra Mundial (1939) abririam uma ferida na história e na alma do povo espanhol.

"Era uma vez em 1940. Em algum povoado da meseta castelhana". Assim Victor Erice inicia seu filme, leva-nos para o centro dos campos de Castela e propõe uma de suas encruzilhadas de leitura. A estrutura inicial é a mesma dos contos infantis e, nesse sentido, entramos no universo da ficção e do cinema. A data, 1940, no entanto, nos dá a referência histórica - um ano depois do final da Guerra Civil e há um ano de combates entre as potências europeias. Fatos que nos reportam ao universo do real. Entre a realidade e a ficção: Castela. Símbolo de um esplendor guerreiro em estado decrépito e esquelético, escrevia Antonio Machado em Campos de Castilla publicado em 19124.

Castela não foi escolhida ao acaso se pensarmos que esse livro de Machado, repleto de paisagens e de pessoas, é considerado por estudiosos do poeta como um livro de meditações sobre os enigmas do homem, do mundo e da realidade espanhola. Composto por poemas que evocam ao mesmo tempo o passageiro e o eterno, no Campos de Castilla eles relatam de maneira emocionada e austera a trágica Espanha da Geração de 1889. Geração a que pertenciam, entre outros intelectuais e artistas espanhóis, Antonio Machado e Miguel de Unamuno. Se nos poemas De un cancionero apócrifo podemos perceber que Antonio Machado sente toda a justiça e nobreza da guerra dos republicanos espanhóis, e, por conseguinte desde tal guerra execram a ignóbil paz das potências que se preparam para a outra guerra, o olhar e a meditação sobre as paisagens e os habitantes dos campos de Castela, bem como a ruína das velhas cidades castelhanas, podem ser visualizados em um dos trechos do poema "A orillas del Duero" de 1912. Escreve Machado:

4.MACHADO, Antonio. Campos de Castilla. Edição de Geoffrey Ribbans. Madrid: Cátedra, 1997. 
comunicação \& educação • Ano XXV • número 1 • jan/jun 2020

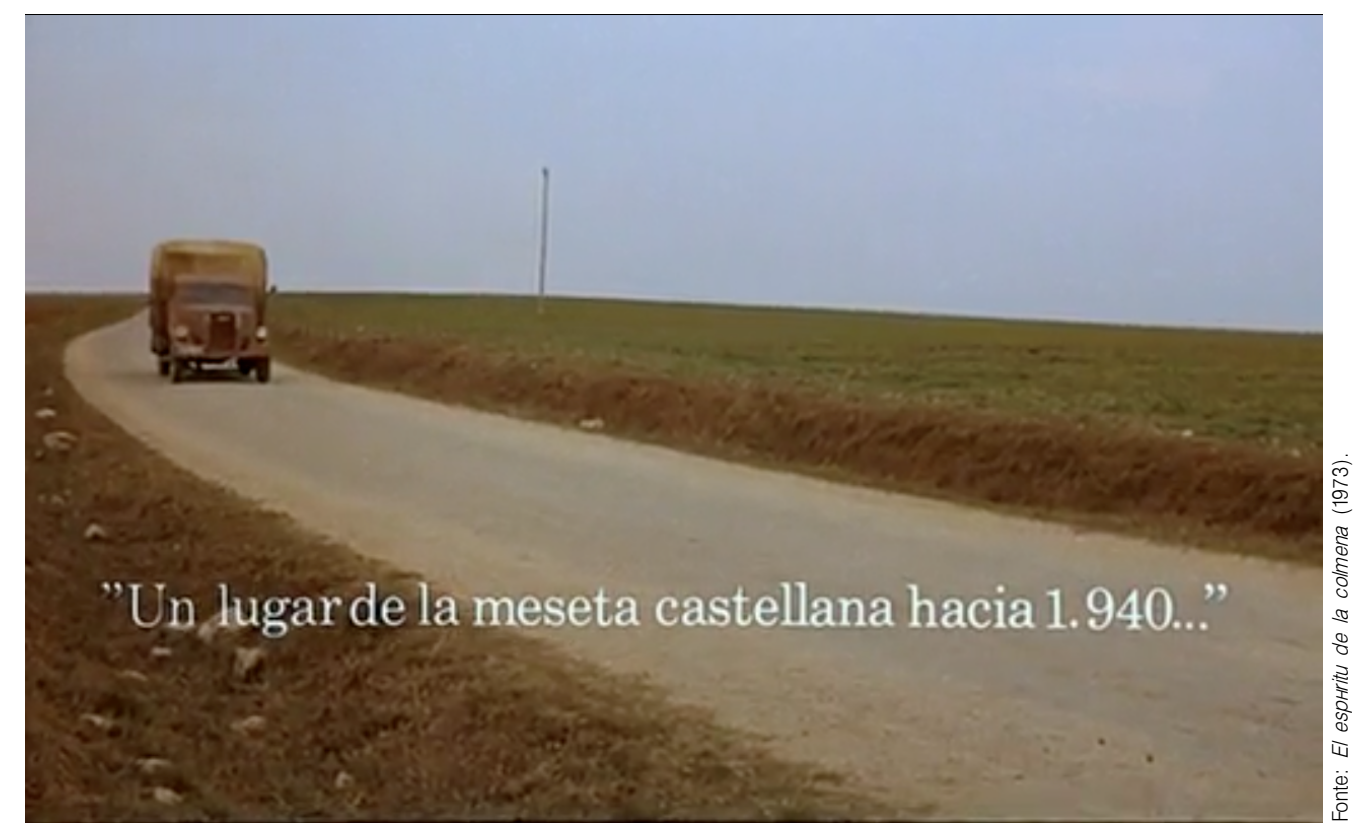

Figura 1: Início

5. "Às margens do Douro". "O Douro cruza o coração de roble da lbéria e de Castela. $\mathrm{O}$, terra triste e nobre a dos grandes planaltos dos ermos e rochedos, de campo sem arados, regatos e arvoredos; decrépitas cidades, caminhos sem pousadas e atônitos grosseiros sem danças nem baladas que vão, abandonando o moribundo lar, como teus longos rios, Castela, para - mar!" MACHADO, Antonio. Antologia. In: CATA L̃̃O, Marco Aurélio Pinotti. Antologia e tradução comentada da obra de Antonio Machado. 2002 Dissertação (Mestrado em Teoria e História Literária - Universidade Estadual de Campinas, Campinas, 2002 p. 41-316. p. 134.

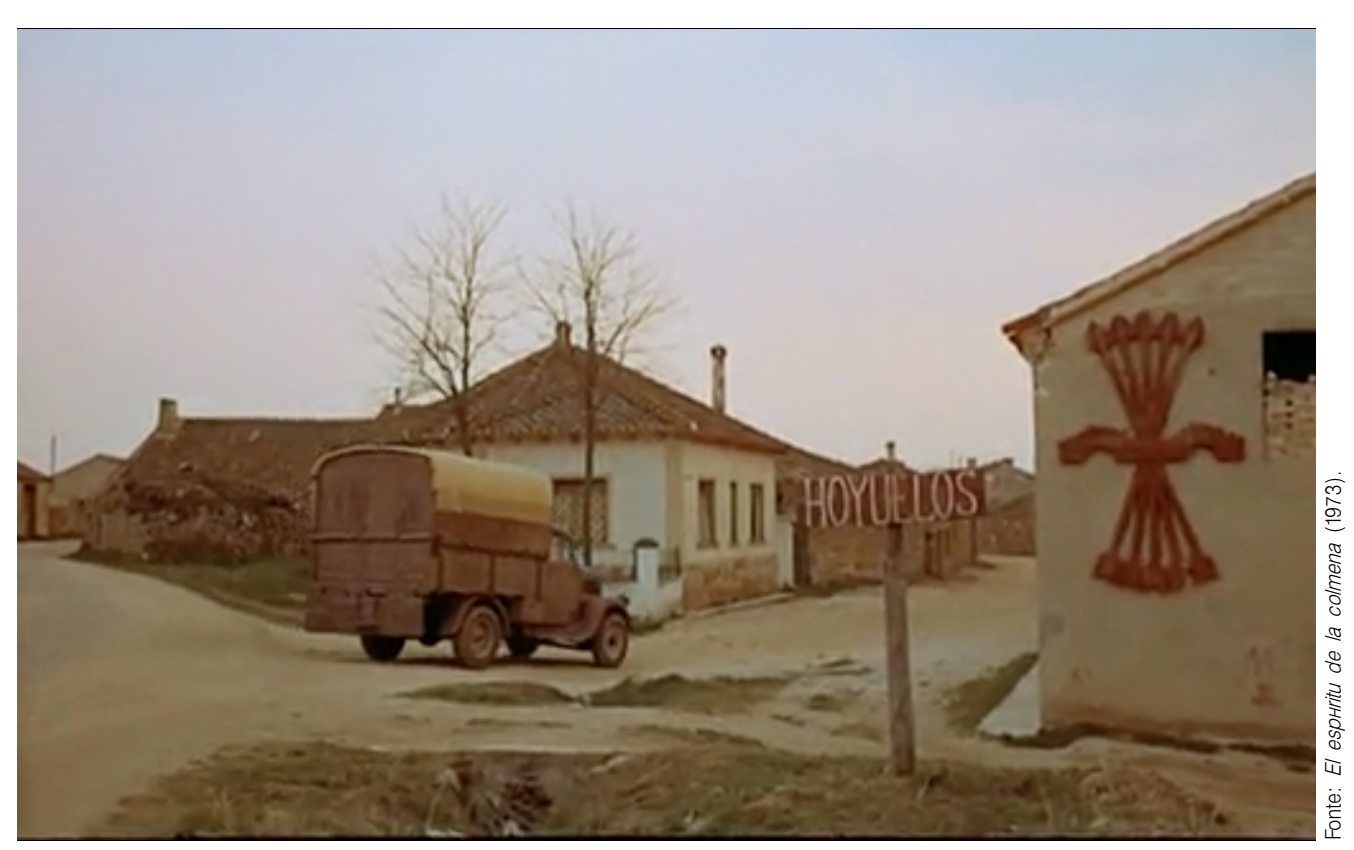

Figura 2: $\mathrm{O}$ caminhão-cinema entrando na aldeia

El Duero cruza el corazón de roble de Iberia y de Castilla. ¡Castilla, oh tierra triste y noble, la de los altos llanos y yermas y roquedas, de campos sin arados, regatos, ni arboledas, decrépitas ciudades, caminos sin mesones y atónitos palurdos sin danzas ni canciones que aún van, abandonado el mortecino hogar, con tus largos ríos, Castilla hacia la mar! $!^{5}$ 
Se atentarmos para as primeiras imagens do filme de Erice, num longo e bem determinado plano acompanhamos um caminhão percorrendo os campos de Castela. Quando o caminhão entra na vila o que vemos são antigos e abandonados casarões. Aparentemente em paz, o que sentimos é uma grande ausência de vida. O que ficamos sabendo é que o caminhão que trazia o cinema para os habitantes daquele lugar anunciava também o início da narrativa do filme. A letargia do lugar só é quebrada com a chegada do cinema. Esperado por todos, principalmente pelas crianças em algazarra, o cinema levava o sonho e o monstro Frankenstein. Como palavras e imagens sempre nos remetem a outras palavras e imagens, o poema que lembrou essa sequência e cena foi: "La plaza y los naranjos encendidos" de 1907.

La plaza y los naranjos encendidos, con sus frutos risueños. ¡Tumulto de pequeños colegiados que, al salir en desorden de la escuela llenam al aire de la plaza en sombra con la algazarra de sus voces nuevas! Alegria infantil en los rincones de las ciudades muertas!. ¡Y algo nuestro de ayer, que todavía vemos vagar por estas calles viejas! $!^{6}$

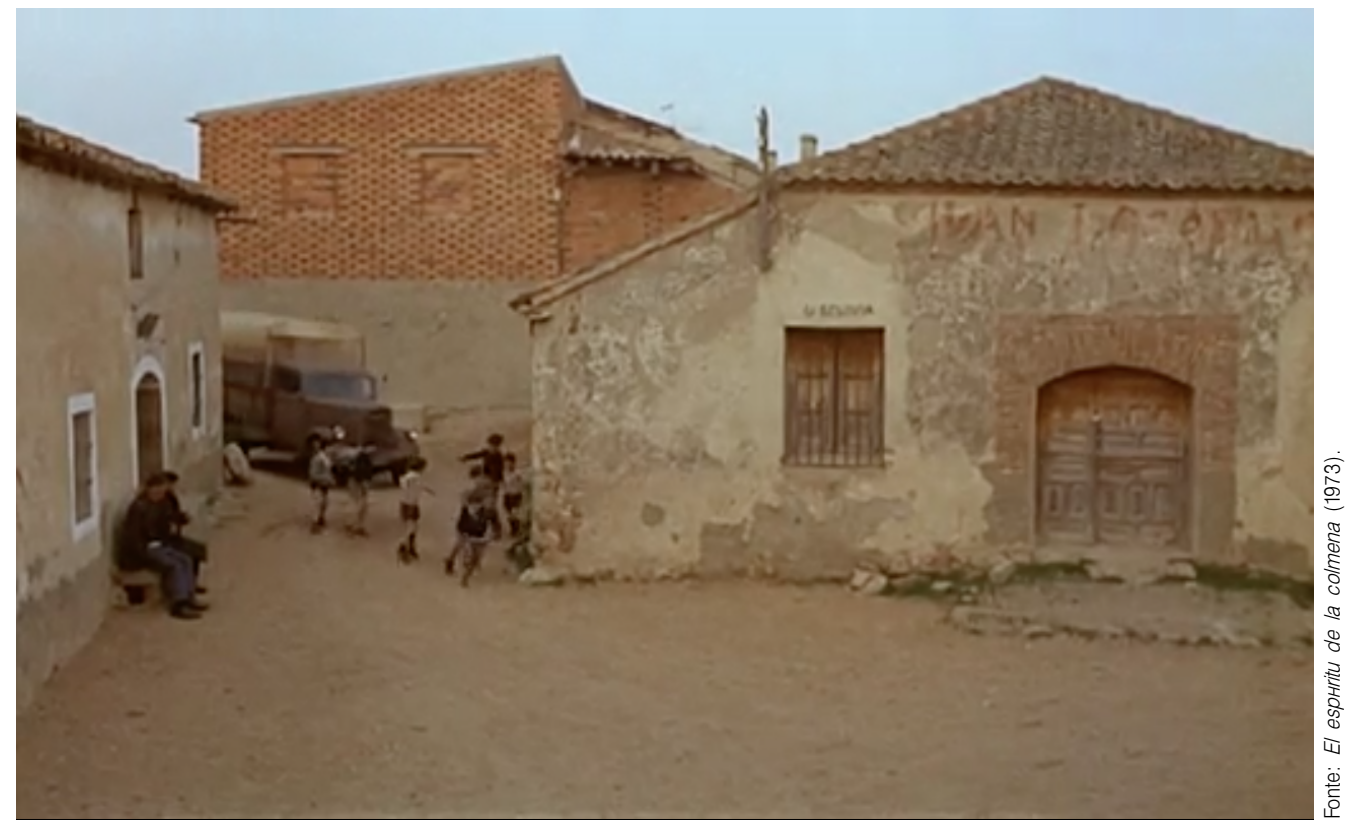

Figura 3: Crianças e o caminhão-cinema

No jogo dos opostos de que a poesia machadiana está repleta, num território ambíguo, num estado intermediário entre guerra e paz, entre terra e lua, entre ficção e realidade, entre passado e presente, Erice teceu suas líricas imagens e íntimas reflexões sobre a guerra e sobre a alma espanhola do pós Guerra Civil.

Outra lembrança a que a sequência do caminhão-cinema chegando à cidade diz respeito é a da Segunda República Espanhola, que tinha como uma de suas preocupações levar todo tipo de produção cultural até os lugares mais distantes, período em que as missões pedagógicas saíam para os campos e aldeias apresentando peças teatrais, jornais, rádio e tudo o que fosse possível.
6."A praça e as laranjeiras acenderam". "A praça e as laranjeiras iluminadas, com seus frutos sorridentes. Tumulto de pequenos colegiais, que ao saírem da escola em desordem, enchiam o ar da praça em sombra com a algazarra de suas vozes novas! Alegria infantil nos cantos das cidades mortas. E algo nosso de ontem, que ainda vemos vagando por essas velhas ruas!" (tradução nossa). MACHADO, Antonio. La plaza y los naranjos encendidos. In: MACHADO, Antonio. Poesías Completas: Soledades (1899-1907). Madrid: Espasa-Calpe, 1979. p. 4. 


\section{comunicação \& educação • Ano XXV • número 1 • jan/jun 2020}

Claro que não podemos resumir o filme unicamente aos seus referentes sociais e históricos, embora eles sejam fortes. El espíritu de la colmena ultrapassa e supera tais conceitos na medida em que transcende em direção a uma cosmovisão, como assinalam alguns teóricos do cinema espanhol. Para José Enrique Monterde $^{7}$, os aspectos simbólicos do filme não se manifestam através dos diálogos ou em construções-chave, mas por meio da iluminação, da criação de um agonizante ambiente visual e sonoro, dos gestos sem palavras, dos jogos e rituais infantis, são outras tantas sugestões da leitura simbólica que o filme nos oferece. Exatamente quando essa cosmovisão se tornou o referencial do filme, ele se fez mais crítico e reflexivo porque a metáfora não é só a tessitura de abstrações, mas sim o mergulho no concreto, no reino da duração pura.

Intimismo crítico que Victor Erice construiu através das personagens Fernando e Teresa. Machado e Unamuno. Mergulho plasticamente montado para descer à mais profunda raiz da alma e tentar trazer à superfície o sentido de uma guerra que mutilou e fragmentou toda a estrutura social, cultural e familiar espanhola.

O cinema foi o elemento mediador entre ficção e realidade. O veículo real, concreto e capaz de criar, através da montagem, as mais lindas e terríveis imagens. Por tudo poder dizer, ele é o truque. Diferentemente do rádio, das revistas ou das cartas, que traziam as notícias do mundo além dos Pirineus, o cinema trouxe a ficção e o sonho. Como nem todos os sonhos são bons, a película levou o monstro para a aldeia onde viviam Teresa, Fernando e as crianças.

Erice não buscou qualquer monstro para compor sua metalinguagem. Buscou Frankenstein. Mesmo tendo declarado que a intenção primeira era a de recuperar um dos mitos de sua infância e de gerações passadas, Frankenstein também representava o conteúdo simbólico que transcende a ideia original do diretor. Erice admitiu, ao falar das personagens Fernando e Teresa, que caiu no domínio do mito, girando em torno de uma estrutura lírica. Uma mistura de recordações e princípio do trabalho da memória. Vale ressaltar que Erice nasceu em 1940, em Karrantza Harana um município da Espanha na província de Biscaia, comunidade autônoma do País Basco.

Mesmo que os elementos utilizados como referenciais concretos para a construção do texto fílmico tenham sidos trabalhados por críticos e estudiosos do cinema de maneira exaustiva; mesmo sabendo que a figura de Frankenstein sugere identificações óbvias como: monstro símbolo da guerra, monstro-franquismo, monstro-pai, monstro que, como sua própria figura,

7.MONTERDE, José Enrique. Veinte años de cine español (1973-1992) un cine bajo la paradoja. Barcelona: Paidós, 1993.

8.FRANKENSTEIN. Filme Direção de James Whale. Roteiro baseado na novela de Mary Shelley. Produção de Carl Laemmle Jr., Gênero terror, Música de Bernhard Kaun, . Estados Unidos, : Universal Pictures, 1931.71 minutos. é retalhado, mutilado e absurdamente triste porque não tem alma, porque não tem um espírito, é importante observar qual Frankenstein Erice elegeu e como foi trabalhado em El espiritu de la colmena.

O Frankenstein a que as crianças assistem é o de James Whale de $1931^{8}$, que é em branco e preto. A sequência projetada na tela em El espíritu de la colmena é a do monstro sendo conduzido pela mão de uma menina até um rio para ver flutuar diminutas margaridas brancas. Pequenas margaridas brancas dos campos de Sória. 


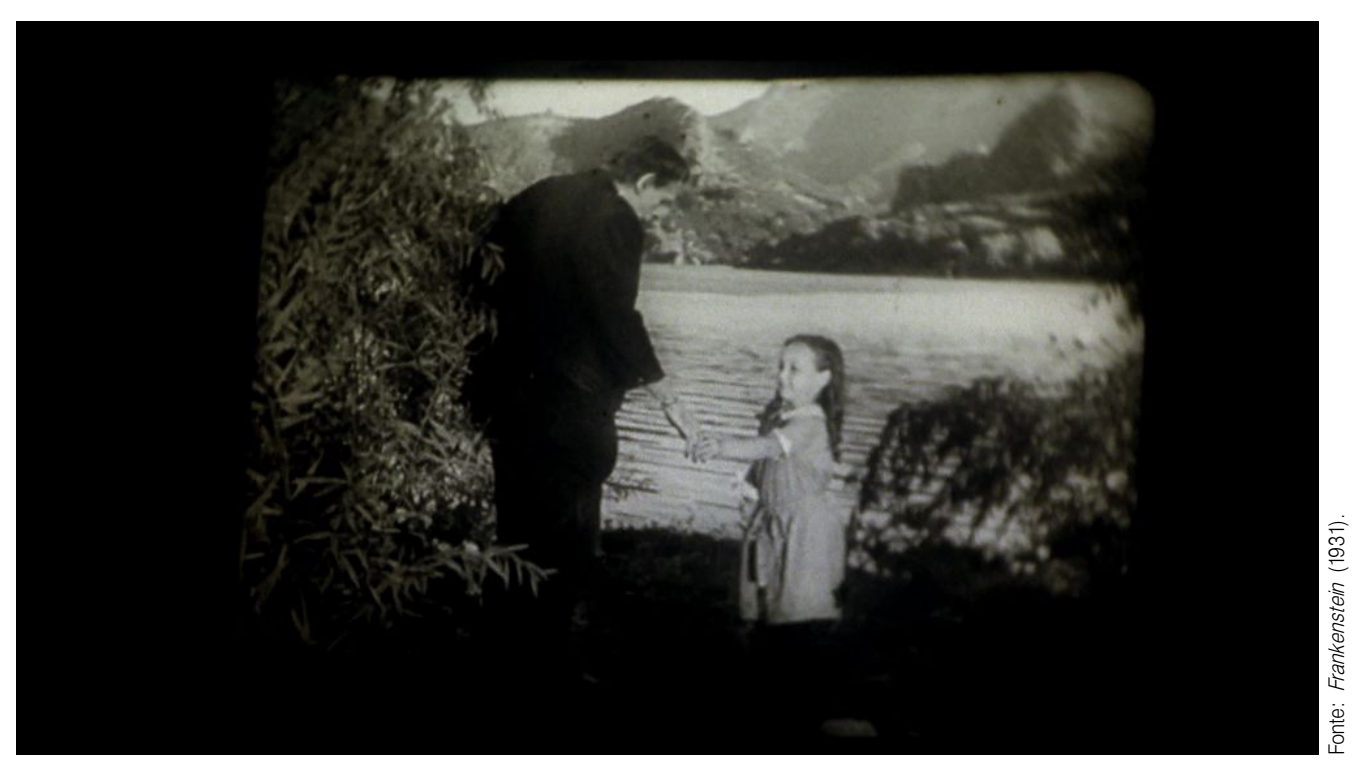

Figura 4: Frankenstein e a menina no lago

Igual ao descrito no início do poema "Campos de Soria”, de 1912, de Machado:

En la tierra árida y fría. Por las colinas y las sierras calvas, verdes pradillos, cerros cenicientos, la primavera pasa dejando entre las hierbas olorosas sus diminutas margaritas blancas. ${ }^{9}$

Tanto o poema "Campos de Soria" como Guiomar são figuras-chave e ao mesmo tempo enigmáticas nos textos de Machado. O poema faz parte do período que viveu em Soria e seus poemas fundem paisagens e críticas sobre a evolução da Espanha. A meditação, a narração e a descrição de paisagens evocam sentimentos no poeta. Guiomar é um enigma na obra de Machado. Era Pilar Valderrama com quem Machado manteve uma relação sentimental durante vários anos, mas também pode ter sido o seu heterônimo feminino. $\mathrm{Na}$ meseta castelhana vagavam fantasmas e monstros.

No filme de Erice o que vemos é uma dupla aparição inicial do monstro. O monstro do filme e o monstro-apicultor. O indício da identificação monstro-pai é imediato, uma vez que a primeira imagem por detrás da máscara do apicultor está disforme e distorcida. Máscara que é lentamente retirada ao som da voz em off de Teresa lendo uma carta. A voz de Teresa parece colada aos pensamentos de Fernando.

9." Campos de Soria". "É a terra de Soria, árida e fria. Pelas colinas, pelas serras calvas, verdes campinas, outeiros cinzentos, a primavera passa deixando em meio às ervas olorosas suas pequenas margaridas brancas". MACHADO, op. cit., 2002, p. 140-143. 
comunicação \& educação • Ano XXV • número 1 • jan/jun 2020

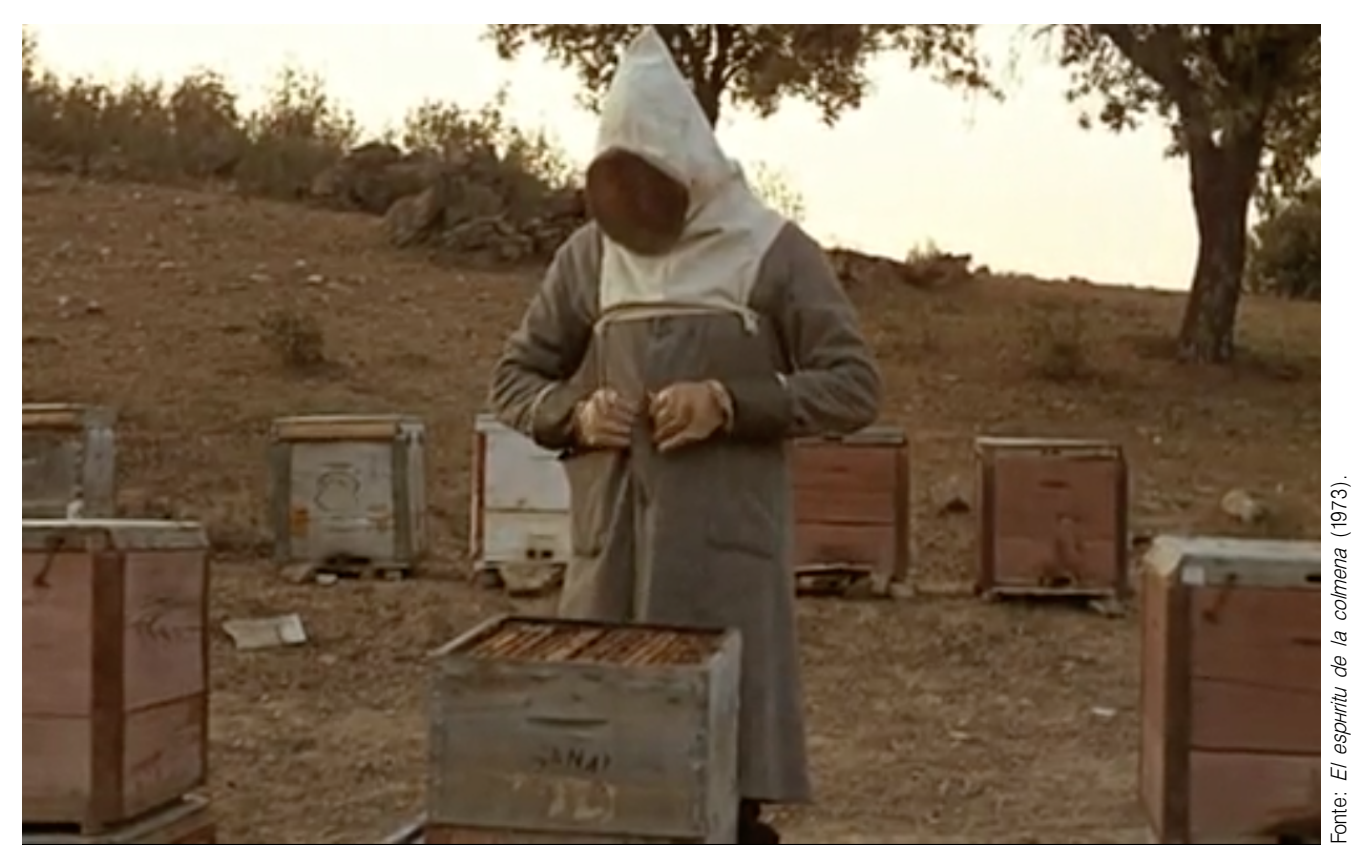

Figura 5: Fernando e as colmeias

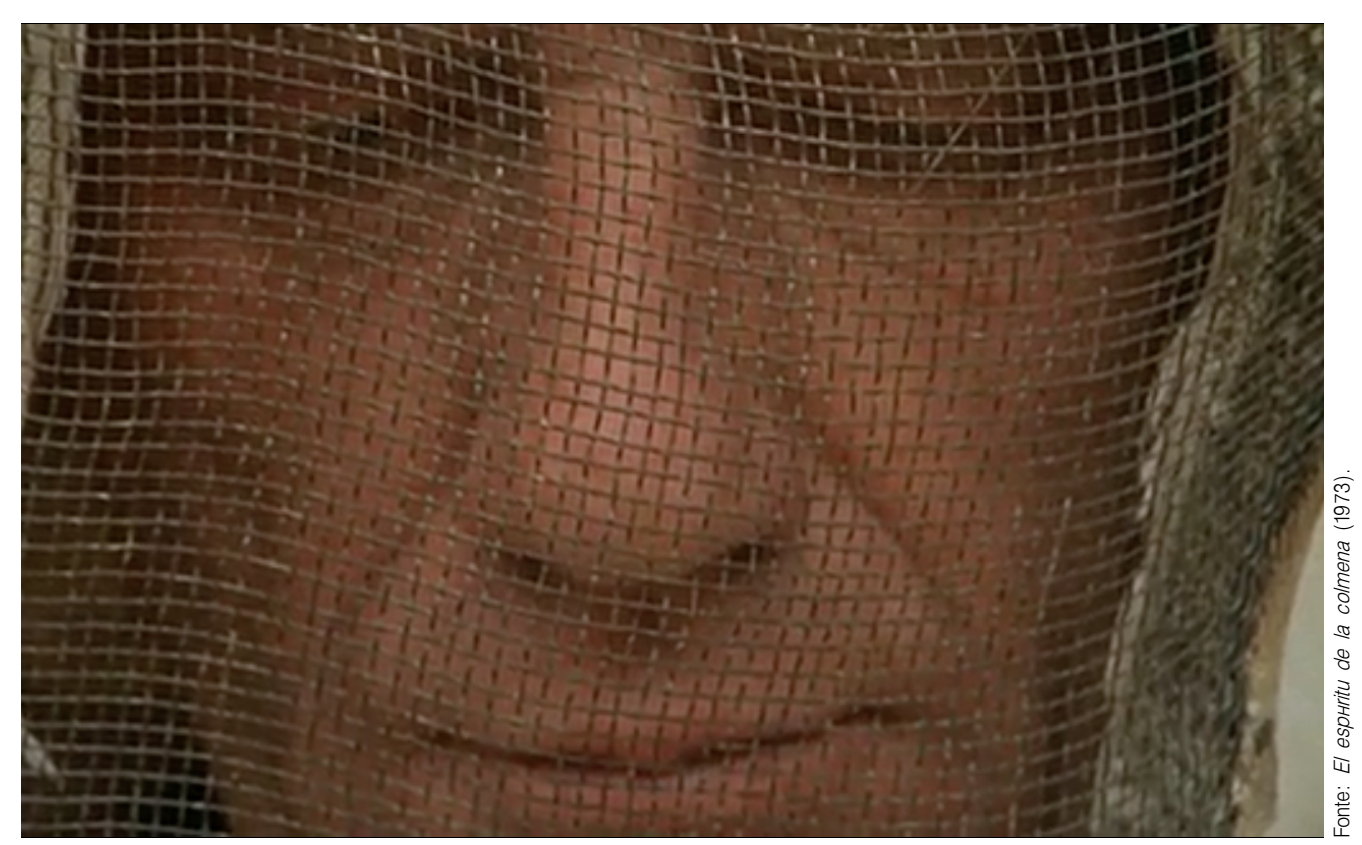

Figura 6: Detalhe do rosto de Fernando

A partir dessa sequência, Erice inicia suas reflexões sobre os fantasmas sobreviventes, sobre a luta e a agonia poética, sobre espaços e tempos, sobre o passado e o presente. Ao deslocar o espaço da guerra para o espaço familiar e, principalmente, para o interior de cada uma das pessoas, o diretor funde personagens, tempos e sentimentos. Nos moldes da poética machadiana, 
variando entre opostos, entre o lírico e o filosófico, utiliza-se de uma série de imbricações entre Teresa e Fernando, Unamuno e Machado, para olhar dentro da história e tentar responder a uma das questões de José Enrique Monterde sobre a visão centrada que existia na maior parte dos filmes dos anos 1970 .

Se tomarmos a carta que Teresa escrevia como ponto de partida para entendermos o jogo que Erice faz, podemos perceber numa primeira leitura que ela expressa o desejo de realidade. Nesse sentido, os movimentos todos da personagem se direcionam para fora, para o exterior. Teresa sabe que a realidade jamais será a mesma, que nada vai voltar a ser como antes, mas pede a Deus, o reencontro.

Além da ambiguidade explicitada e não resolvida, a carta de Teresa condensa três realidades: a da guerra e suas consequências; a realidade íntima que só ela conhece, mas nos dá pistas, e uma realidade existencial e familiar. Na carta de Teresa também se encontram três poemas de Machado lidos à luz de Unamuno, ou Rafael, poeta desconhecido. Poemas que nos apontam mais de uma leitura em função das imagens montadas sobre eles.

O primeiro é o poema "En tren" do qual podemos retirar a ideia de esperança, do desejo de contato com o mundo: "luego el tren, al caminar siempre nos hace soñar: y casi, casi olvidamos el jamelgo que montamos" 10 . Mas também pode estar relacionado com o movimento constante do relógio, sempre em direção ao futuro. Nesse sentido, um tempo fluido, em constante movimento. Tempo sem retorno. Tempo da cotidianidade, da casa, dos filhos, de Fernando, de Teresa.

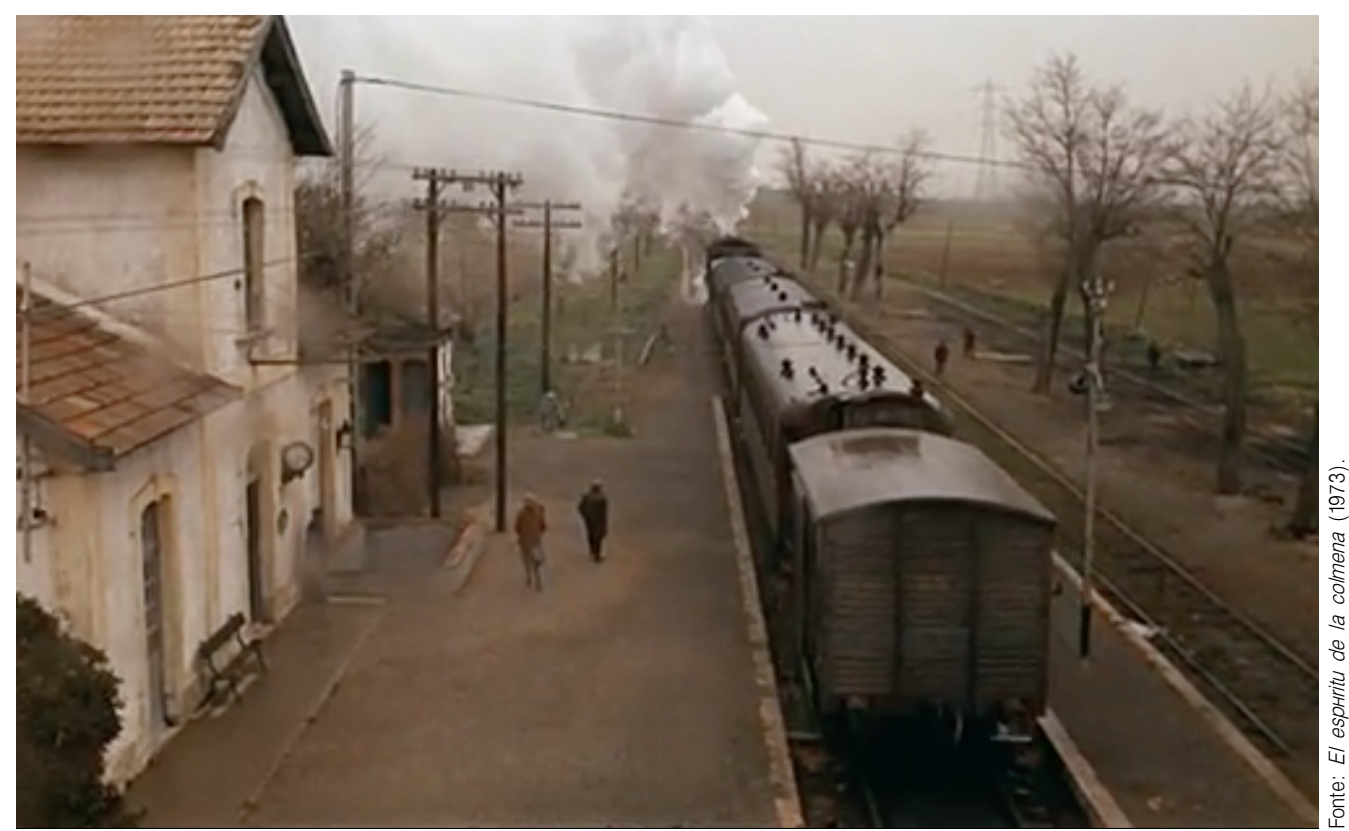

Figura 7: Teresa, a estação de trem, o relógio, o trem em movimento

10." De trem". "Logo, o trem, ao caminhar, sempre nos põe a sonhar; e quase, quase esquecemos o pangaré que montamos". MACHADO, op. cit., 2002, p. 138. 
Teresa evoca um tempo passado e feliz que a guerra interrompeu, estilhaçou e fez secar todo e qualquer afeto entre as pessoas. Tempo suspenso, sem ódio e sem amor. Apenas solidão e saudade. Ao longo do filme uma pergunta nos acompanha: para quem Teresa escrevia? E outro poema: "El viajero", de 1907, se coloca frente à ambiguidade da carta.

Está en la sala familiar, sombría, y entre nosotros, el querido hermano que en el sueño infantil de un claro día vimos partir hacia un país lejano. [...] Y este dolor que añora o desconfía el temblor de una lágrima reprime [...] serio retrato en la pared clarea todavía. Nosotros divagamos. En la tristeza del hogar golpea el tic-tac del reloj. Todos callamos. ${ }^{11}$

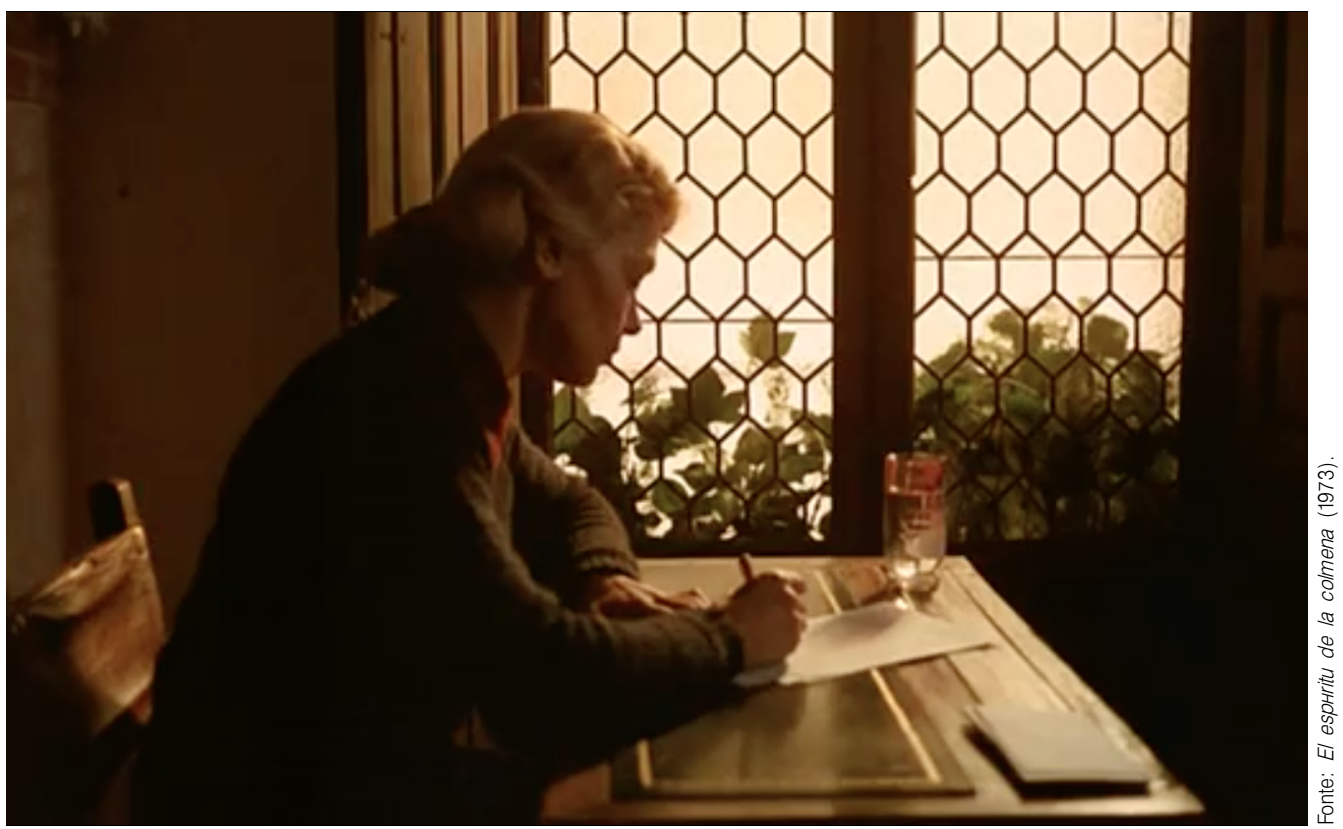

Figura 8: Teresa escrevendo. Para quem escrevia?

11."O viajante". "Nesta sala familiar, sombria, e entre nós, o querido irmão que em sonho infantil de um dia claro vimos partir para um país distante [...]. E esta dor que anseia ou desconfia o temor de uma lágrima reprime [...] Serio retrato na parede clareava. Nós divagamos. Na tristeza do lugar bate o tic-tac do relógio. Todos calamos." (tradução nossa). MACHADO, Antonio. El viajero. In: MACHADO, op. cit., 1979. p. 3.

"E agora nesse lugar distante Fernando, as meninas e eu, tratamos de sobreviver". Teresa finaliza a carta enquanto o filme nos mostra, por meio de suas lembranças, a casa que a carta pressupõe conhecida desde tempos longínquos. Como síntese explicativa desta carta, e de tudo que nela estava escrito, se dá o momento em que a filha Ana folheia um álbum de fotografias. A cada página virada, as fotos mostram tempos e pessoas ausentes, abraços, sorrisos em torno de alguma coisa ou alguém. Agora, só ausência. São duas as fotos em que Ana se detém, em uma delas está Miguel de Unamuno; na outra, uma dedicatória lida em voz alta por Ana: "Ao meu querido misantropo. Teresa". Teresa também é um poema, ou um dos muitos poemas de Unamuno, escrito sob o heterônimo de Rafael.

"Ao meu querido misantropo" pode ser um ponto inicial para compreendermos Fernando, sua obsessão pelas abelhas e sua profunda melancolia. Numa sequência em que Fernando sai do apiário, passa em frente à prefeitura da cidade e segue em direção a casa, Erice mostra duas narrativas sobre Fernando. 
Uma é a visão de Ana e a outra a do próprio Erice. Se seguirmos a trajetória de Fernando, desde o apiário, pelos olhos de Ana, as imagens simultâneas são de Fernando e do monstro até sua chegada em casa. Se acompanharmos as imagens de suas botas subindo as escadas em direção aos quartos, em revista à família para se certificar se tudo estava em ordem, podemos concordar que uma leitura previamente estabelecida faça parte do jogo entre uma ordem externa a casa e uma interna a casa, entre a relação de Ana com o pai.

No entanto, se voltarmos ao filme e olharmos para a trajetória de Fernando desde o apiário até sua casa, a passagem em frente à prefeitura da cidade, a chegada em casa perguntando por todos e pela comida, o que vemos é um rito cotidiano. Mas a câmera de Erice nos faz acompanhar o caminho de Fernando dentro da casa, suas botas subindo as escadas, e, diferente do que estávamos esperando, Fernando entra em um quarto vazio e sombrio. E tanto sua obsessão pelas abelhas como os motivos de sua profunda melancolia se revelam.

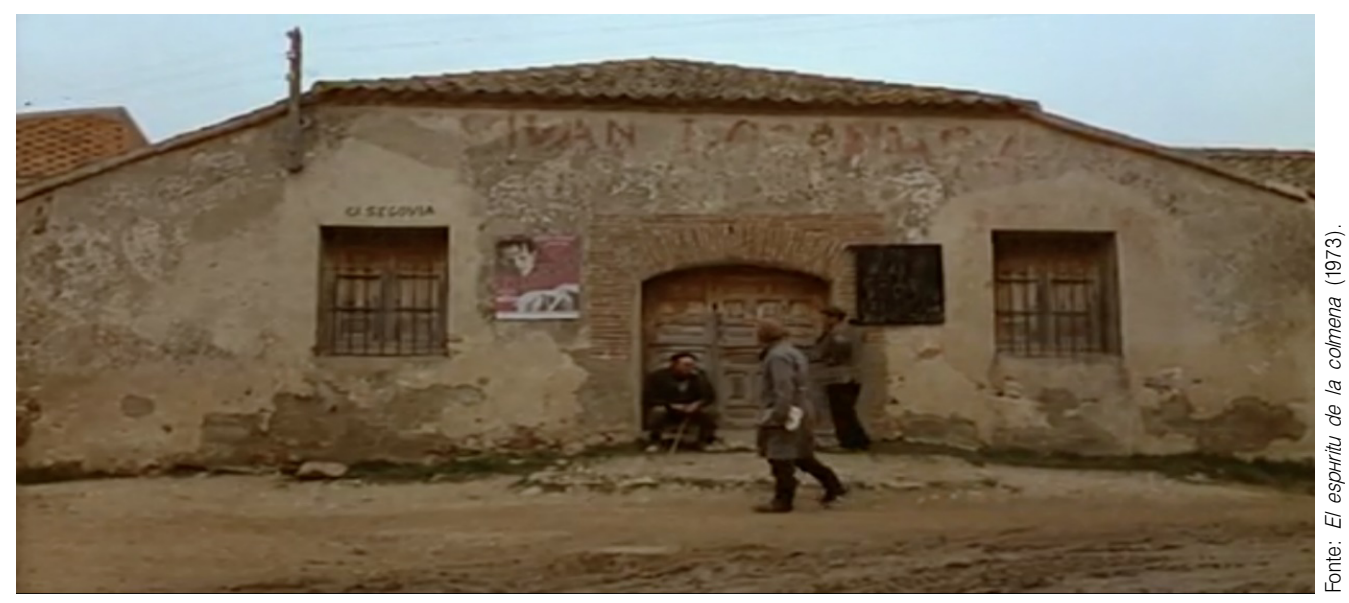

Figura 9: Fernando caminhando em direção a casa

Ao contrário do que parecia, a alienação de Fernando perante os acontecimentos do mundo é aparente. A revista que lê se chama "O Mundo" e a rádio que ouve é a "Rádio Espanha Independente". Fernando vai até a janela que reproduz as formas de uma colmeia e contempla o horizonte enquanto o locutor da Rádio Espanha Independente noticia o mundo. Segundo Erice, a imagem inicial seria a sombra de Fernando contemplando o mundo. Imagem que Erice mudou por considerar grande demais o isolamento de Fernando e colocou então uma colmeia e um sol em seu coração.

Colocou uma colmeia e um sol no coração de Fernando. Imagens que vão muito além das formas geométricas da janela. Um coração-colmeia que à noite se misturava aos fantasmas, aos sonhos, aos desejos irremediavelmente reprimidos, às recordações e às sombras. Colmeia que era a ebulição aprisionada como sua alma em velhas amarguras. E para Fernando, Erice buscou uma das mais significativas poesias de Antonio Machado, "Anoche cuando dormia" de 1912: 
comunicação \& educação • Ano XXV • número 1 • jan/jun 2020

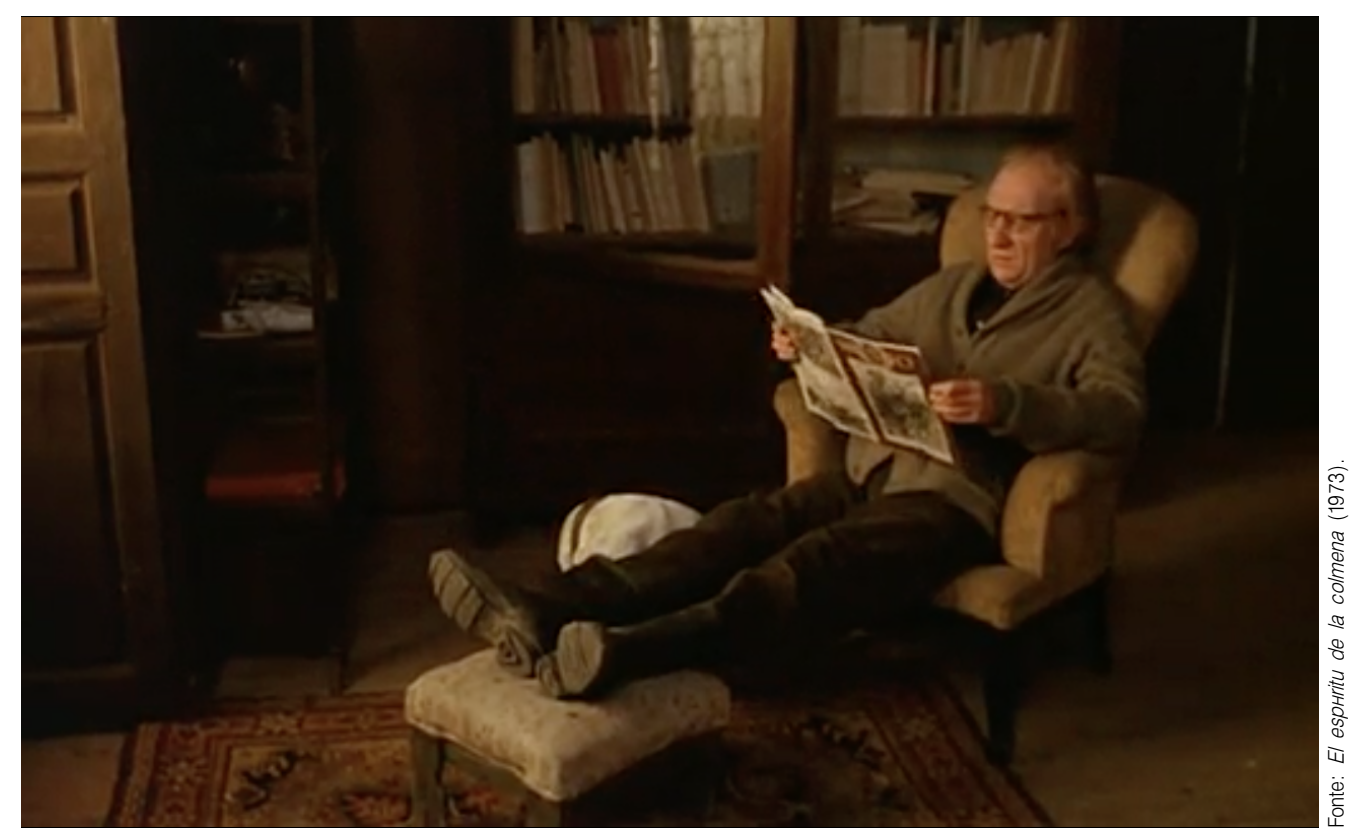

Figura 10: Fernando em seu quarto lendo a revista "O Mundo"

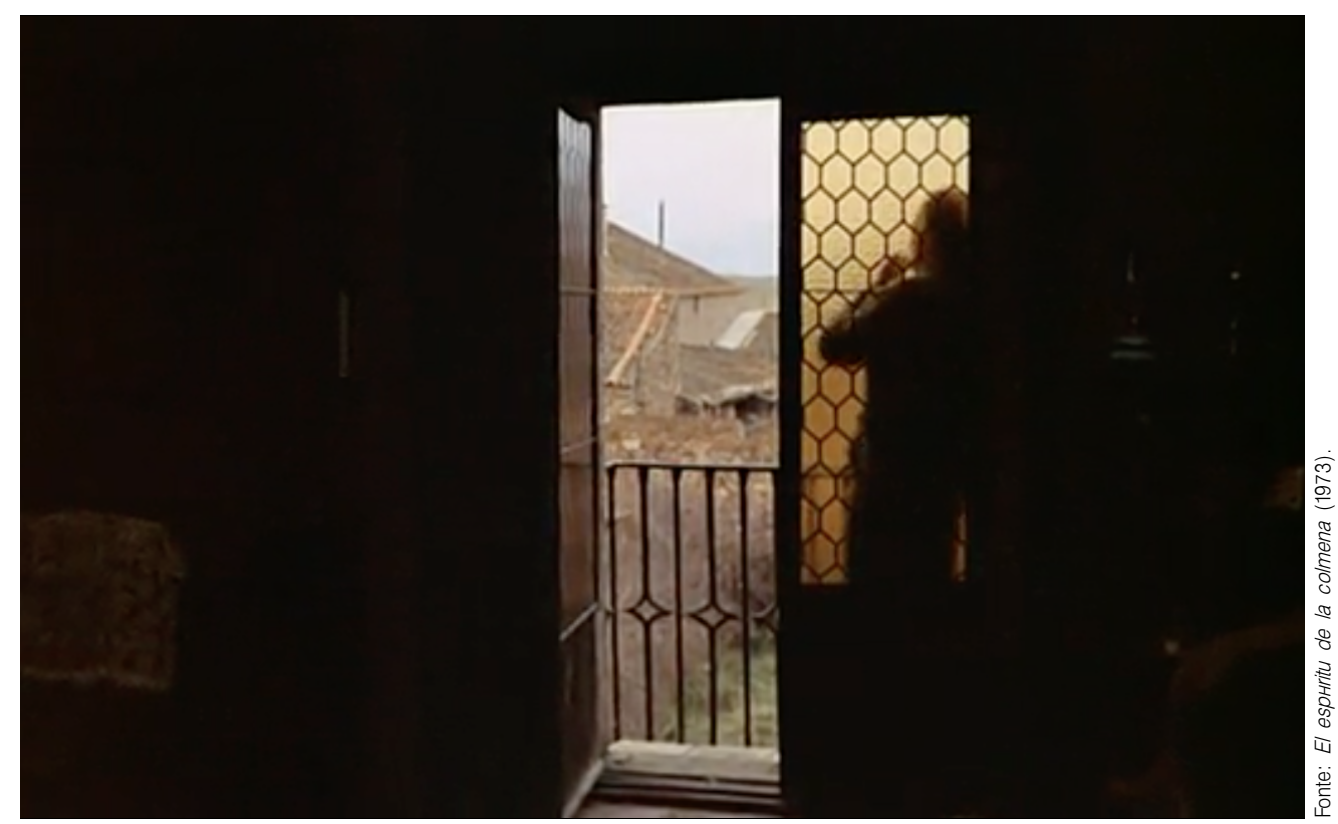

Figura 11: Fernando contemplando o horizonte por detrás da janela em formato de colmeia

Anoche cuando dormía, Soñé! ¡Bendita ilusión! que una colmena tenía dentro de mi corazón; y las doradas abejas iban fabricando en él, con las amarguras viejas, blancas cera y dulce miel. ${ }^{12}$ 
Colmeia que se sustenta, que não se projeta, e que fabrica o homem-abelha que reproduz o mel e fere. Colmeia que acoplada ao monólogo de Fernando ganha outra dimensão e a imagem que temos são trincheiras, "atividade incessante da multidão", de homens, mulheres e crianças, que muito antes das Brigadas Internacionais se organizarem e chegarem à Espanha para defender a República, já combatiam e morriam para conter o avanço da direita armada. Abelhas-homens em "esforço inútil de idas e vindas com ardor febril". Homens e mulheres com colmeias e sóis no coração e "um grande sonho ignorado", pensava Fernando em conversa consigo mesmo.

Monólogo que igual à carta de Teresa evoca tempos, memórias, saudades, solidão. Monólogo que à primeira vista é oposto ao de Teresa. Lendo e ouvindo com um pouco mais de cuidado, descobrimos que são próximos e convergentes em seus desejos. São diferentes, porque a relação de Teresa e Fernando com a realidade é diferente. Fernando é o interior, a alma-espelho, labiríntica e noturna. Os poemas e as imagens de Fernando são sempre aqueles que transitam do tédio para a alma pura. O tempo que Fernando evoca é o de uma realidade que vem acompanhada do tempo-relógio. Cristalino e sonoro. Sempre a mesma música triste. Relógio e música que levam Fernando para um tempo que se perdeu, mas que permanece no fundo de sua alma triste como a noite: "Sonaba el reloj la una, dentro de mi cuarto. Era triste la noche"13, tempo invisível que Fernando associa à roda do relógio. Tempo fluído, porém, concretamente sentido no corpo de Fernando no apiário, na estação de trem, no quarto.

Seu monólogo se aproxima ao de Teresa na evocação de um tempo real, quando os movimentos das pessoas podiam ser vistos e elas ainda eram capazes de sentir, desejar e chorar, "que un ardiente sol lucía dentro de mi corazón. Era ardiente porque daba calor de rojo hogar, y era sol porque alumbraba y porque hacía llorar"14.

Os textos se aproximam no desejo do reencontro e em poder novamente olhar o horizonte, curados da profunda enfermidade: a tristeza de um grande sonho ignorado. Fernando sonha. Teresa demonstra um único gesto de afeto ao tirar os óculos de Fernando, cobrir suas costas e fechar o caderno onde registrava suas íntimas reflexões. Pássaros de origami velam o sono e os gestos. E Erice já pode responder a Monterde.

Numa clara homenagem a Unamuno, Fernando pratica a técnica introspectiva, centrada, do origami e constrói mil sóis pássaros/imagens até retornar do mergulho na história e no fundo da alma, na negatividade dos afetos instaurados pela guerra.

\section{REFERÊNCIAS BIBLIOGRÁFICAS}

CAMUS, Albert. ¡España Libre! Madrid: Júcar, 1978. (Coleção Crónica General de España).

EL ESPÍRITU de la Colmena. Direção de Victor Erice. Roteiro de Victor Erice e Ángel Fernandez Santos. Produção de Elias Querejeta. Música de Luis de

13."Tocava o relógio a uma hora dentro do meu quarto. Era triste a noite" (tradução nossa).

14."que um ardente sol luzia, dentro do meu coração. Era ardente porque dava calores como os de um lar, e sol, porque iluminava e me fazia chorar." MACHADO, op. cit, 2002, p. 87-89. 
Pablo. Fotografia de Luis Cuadrado. Montagem de Pablo G. Del Amo. [S. l.]: Elías Querejeta Producciones Cinematográficas S.L., 1973.

FRANKENSTEIN. Direção de James Whale. Roteiro baseado na novela de Mary Shelley. Produção de Carl Laemmle Jr. Música de Bernhard Kaun. Estados Unidos: Universal Pictures, 1931.

MACHADO, Antonio. Poesías Completas: Soledades (1899-1907). Madrid: Espasa-Calpe, 1979.

MACHADO, Antonio. Campos de Castilla. Edição de Geoffrey Ribbans. Madrid: Cátedra, 1997.

MACHADO, Antonio. Antologia. In: CATALÃO, Marco Aurélio Pinotti. Antologia e tradução comentada da obra de Antonio Machado. 2002. Dissertação (Mestrado em Teoria e História Literária) - Universidade Estadual de Campinas, Campinas, 2002. p. 41-316.

MONTERDE, José Enrique. Veinte años de cine español (1973-1992): un cine bajo la paradoja. Barcelona: Paidós, 1993.

UNAMUNO, Miguel de. Soledad. In: Obras Completas. Madrid: A Aguado, 1958. t. 3, p. 881-901. 